DOI 10.37882/2223-2974.2020.10.35

\title{
НАЛОГООБЛОЖЕНИЕ ФЬЮЧЕРСА КАК ПРОИЗВОДНОГО ФИНАНСОВОГО ИНСТРУМЕНТА
}

\section{TAXATION OF FUTURES AS A DERIVATIVE FINANCIAL INSTRUMENT}

\section{E. Tokarev}

Summary: The article is based on the research of the legal regulation of the market of derivative financial instruments in the Russian Federation. This analytical work is necessary to substantiate the conclusions in relation to the science of financial law. The purpose of the article is to define the provisions regulating the issue of taxation caused by a special object of legal relations. As a result, the author analyzes the norms of Russian tax law, the provisions of foreign legal systems and concludes that there is no definition of the specifics of the types of derivatives in their taxation.

Keywords: derivative financial instrument, derivative, futures market, taxation, futures.

\author{
Токарев Эдуард Андреевич \\ Аспирант, Российский государственный \\ университет правосудия \\ tok.edward@yahoo.com
}

Аннотация: Статья обусловлена проводимым исследованием правового регулирования рынка производных финансовых инструментов в Российской Федерации. Указанная аналитическая работа необходима для обоснования выводов применительно к науке финансового права. Целью статьи является определение положений, регулирующих вопрос налогообложения, обусловленного особым объектом правоотношений. В результате проанализированы нормы российского налогового права, положения иностранных правовых систем и сделан вывод об отсутствии определения особенностей видов деривативов при их налогообложении.

Ключевые слова: производный финансовый инструмент, дериватив, срочный рынок, налогообложение, фьючерс.

Так в настоящей статье анализируются правовые нормы, регулирующие налогообложение одного из видов производных финансовых инструментов, используемый на отечественном срочном рынке, - фьючерсного договора'.

Согласно пункту 3 Указания Банка России от 16.02.2015 № 3565-У [4], фьючерсным договором признается заключаемый на биржевых торгах договор, предусматривающий обязанность каждой из сторон договора периодически уплачивать денежные суммы в зависимости от изменения цен (значений) базисного актива и (или) наступления обстоятельства, являющегося базисным активом. Фьючерсный договор, может также предусматривать одну из следующих обязанностей:

- обязанность одной стороны договора передать ценные бумаги, валюту или товар, являющиеся базисным активом, в собственность другой стороне или лицу (лицам), в интересах которых был заключен фьючерсный договор, в том числе путем заключения стороной (сторонами) фьючерсного договора и (или) лицом (лицами), в интересах которых был заключен фьючерсный договор, договора купли-продажи ценных бумаг, договора купли-продажи иностранной валюты или договора поставки товара;

- обязанность сторон фьючерсного договора заключить договор, являющийся производным фисовых инструментов [9].

Согласно данным котировок срочных контрактов на 01.09.2020 17:57 объем торгов по фьючерсам на Московской Бирже составил USD 5965927035 (https://www.moex.com/ru/derivatives/). 
нансовым инструментом и составляющий базисный актив.

Данное определение закрепляет за данным видом производных финансовых инструментов возможность обращаться исключительно на организованном рынке, что в соответствии с пунктом 3 статьи 301 НК РФ [3] определяет его как обращающийся на организованном рынке производный финансовый инструмент.

Законодательство Российской Федерации о налогах и сборах устанавливает особые условия для данных видов срочных сделок.

Так, производные финансовые инструменты признаются обращающимися на организованном рынке при одновременном соблюдении следующих условий (подпункты 1, 2 пункта 3 статьи 301 НК РФ):

1. порядок их заключения, обращения и исполнения устанавливается организатором торговли, имеющим на это право в соответствии с законодательством Российской Федерации или законодательством иностранных государств;

2. информация о ценах производных финансовых инструментов публикуется в средствах массовой информации (в том числе электронных) либо может быть предоставлена организатором торговли или иным уполномоченным лицом любому заинтересованному лицу в течение трех лет после даты совершения операции с производным финансовым инструментом.

Таким образом, фьючерсный договор - это стандартизированное соглашение, заключаемое на организованном рынке, о покупке или продаже определенного базисного актива по заранее определенной цене в определенное время в будущем.

Договорная конструкция указанного вида дериватива соответствует нормам Гражданского кодекса Российской Федерации [2] устанавливающего возможность участников гражданских правоотношений заключать договор купли-продажи товара, который будет создан или приобретен продавцом в будущем (пункт 2 статьи 455 ГК РФ), а также закрепляющего право на отсрочку исполнения ими принятых на себя обязательств (пункт 1 статьи 457 ГК РФ).

Исходя из мнения М.Е. Толстухин, правила, изложенные в пункте 2 статьи 455 ГК РФ и в пункте 1 статьи 457 являются основой существования рынка фьючерсов [10].

Согласно позиции Р.Х. Айнетдинова, как правило, целью участников фьючерсной торговли является не приобретение биржевого товара, а игра на разнице цен. Также фьючерсные сделки могут использоваться и с целью хеджирования, т.е. страхования риска потерь от повышения цены на биржевой товар (что нежелательно для покупателя фьючерса) или ее понижения (что невыгодно для продавца). Изначально фьючерс был изобретен именно с целью хеджирования [5].

При этом, НК РФ не определяет особенности налогообложения срочных сделок в зависимости от вида производных финансовых инструментов, в отличии от налогового законодательства таких стран, как, например, США.

Нормы американской налоговой правовой системы исходят именно из определения видов производных финансовых инструментов и их налогообложения в зависимости от базисного актива, места заключения сделки (биржевая или внебиржевая) и состава участников сделки [1].

Следует также отметить, что в российском налоговом праве выбор квалификации сделки в качестве операции с производным финансовым инструментом либо в качестве сделки с отсрочкой исполнения является правом налогоплательщика, который обязан отразить его в своей учетной политике.

По мнению М.В. Карасевой, в первом случае речь идет о так называемых расчетных сделках, а во втором о поставочных. При расчетных сделках реальная поставка базисного актива не предусмотрена. Вместо этого одна сторона перечисляет другой определенную сумму денежных средств в зависимости от условий, предусмотренных договором с производным финансовым инструментом. Таким образом, расчетные сделки являются разновидностью условных сделок. Поставочная сделка основана на реальной поставке актива, являющегося предметом производного финансового инструмента. Более того, в пункте 2 статьи 301 НК РФ отмечается, что «критерии отнесения сделок, предусматривающие поставку предмета сделки (за исключением операций хеджирования), к категории операций с финансовыми инструментами срочных сделок должны быть определены налогоплательщиком с учетом политики для целей налогообложения» [6].

Юридическая квалификация договора в целях налогообложения в любой форме осуществляется в целях определения наличия или отсутствия у лица тех или иных налоговых последствий - объекта налогообложения, права на налоговую льготу, налоговый вычет и т.п. [8].

Однако, по справедливому замечанию О.А. Митряшкиной квалификация сделки для целей налогообложения - это составная часть деятельности по применению норм налогового права, и осуществлять 
юридическую квалификацию сделки для целей налогообложения могут только субъекты налогового правоприменения [7].

Соответственно, не смотря на самостоятельное определение вида сделки с своей учетной политики, налогоплательщик несет риск дальнейшей переквалификации сделки налоговым органом либо судом.

Исходя из пункта 1 статьи 304 НК РФ, налоговая ставка по доходам (расходам) по операциям с обращающимися производными финансовыми инструментами составляет 20\%.

В отличии от необращающихся производных финансовых инструментов, фактическая цена сделки с обращающимися производными финансовыми инструментами для целей налогообложения признается рыночной и применяется в целях налогообложения.

В состав доходов по обращающимся производным финансовым инструментам входят как суммы денежных средств, рассчитанные организатором торговли либо клиринговой организацией, причитающиеся к получению налогоплательщиком в течение отчетного (налогового) периода (вариационная маржа), так и иные сум- мы, причитающиеся к получению по таким операциям (пункт 1 статьи 302 НК РФ).

Соответственно, расходами налогоплательщика в данном случае будут являться суммы вариационной маржи, подлежащей уплате налогоплательщиком в течение налогового (отчетного) периода, иные суммы, подлежащие уплате в течение налогового (отчетного) периода по операциям с обращающимися производными финансовыми инструментами, а также стоимость базисного актива, передаваемого по сделкам, предусматривающим поставку базисного актива и иные расходы, связанные с осуществлением указанных операций.

Таким образом, нормы налогового права Российской Федерации устанавливают правовой режим налогообложения срочных сделок в зависимости от того, совершены они на организованном либо неорганизованном рынке вне зависимости от характеристики и правового статуса отдельных видов производных финансовых инструментов.

Стоит также отметить, что операции с производными финансовыми инструментами не подлежат налогообложению по налогу на добавленную стоимость (подпункт 12 пункта 2 статьи 149 НК РФ).

\section{ЛИТЕРАТУРА}

1. 26 U.S. Code $\$ 1256$. Section 1256 contracts marked to market // https://www.law.cornell.edu/uscode/text/26/1256

2. Гражданский кодекс Российской Федерации (часть вторая) от 26.01.1996 № 14-Ф3 // Собрание законодательства Российской Федерации, 29.01.1996, № 5, ст. 410.

3. Налоговый кодекс Российской Федерации (часть вторая) от 05.08.2000 № 117-Ф3 // Собрание законодательства Российской Федерации, 07.08.2000, № 32, ст. 3340.

4. Указание Банка России от 16.02.2015 № 3565-У «0 видах производных финансовых инструментов» (Зарегистрировано в Минюсте России 27.03 .2015 № 36575) // Вестник Банка России, № 28, 31.03.2015.

5. Айнетдинов Р.Х. Правовая природа фьючерсных сделок // Законодательство и экономика. 2012. № 6. С. 28 - 41.

6. Карасева (Сенцова) М.В. Юридическая квалификация сделок в целях налогообложения: два модуса // Финансовое право. 2016. № 12. С. 32 - 36.

7. Митряшкина О.А. Квалификация сделки для целей налогообложения с точки зрения анализа ст. ст. 45 и 301 НК РФ // Налоги. 2018. N 5. С. 17 - 19.

8. Сенцова М.В. Юридическая квалификация сделок в целях налогообложения // Закон. 2012. N 1. С. 123 - 131.

9. Сидоров Д.В. Условия фьючерсных договоров // Юрист, 2005, № 8.

10. Толстухин М.Е. Фьючерс и опцион как объекты фондового рынка // Объекты гражданского оборота: Сборник статей / отв. ред. М.А. Рожкова. М.: Статут, 2007. C. $231-250$.

( ) Токарев Эдуард Андреевич (tok.edward@yahoo.com)

Журнал «Современная наука: актуальные проблемы теории и практики» 